\title{
Impact of oxygen deficiency on the disease status of common dab Limanda limanda
}

\author{
Stig Mellergaard ${ }^{1}$, Else Nielsen ${ }^{2}$ \\ ${ }^{1}$ Danish Institute for Fisheries and Marine Research, Department of Marine Ecology, Fish Disease Laboratory, Bülowsvej 13, \\ DK-1870 Frederiksberg C, Denmark \\ ${ }^{2}$ Danish Institute for Fisheries and Marine Research, Department of Marine Ecology, Charlottenlund Castle, \\ DK-2920 Charlottenlund, Denmark
}

\begin{abstract}
An epidemiological survey of the fish diseases lymphocystis, epidermal papilloma and skin ulcers in common dab Limanda limanda L. was conducted in the southern Kattegat each year in May from 1984 to 1993. During the period of investigation, severe oxygen depletion occurred in late summer 1986 and 1988. After the oxygen deficiency in 1986, the occurrence of lymphocystis and epidermal papilloma increased and peaked in 1989 with prevalences of 14.7 and $3.3 \%$, respectively. The prevalence of skin ulcers never exceeded $0.6 \%$. The relative risk of contracting lymphocystis increased significantly from 1987 to 1991 compared with 1984 to 1986, the period prior to the severe oxygen depletion. A significant increase in the relative risk of contracting epidermal papilloma was observed from 1987 to 1990. Females were 3 times more likely to contract this disease than males. The relative risk of skin ulcers did not change significantly during the investigation period. The prevalence of lymphocystis and epidermal papilloma was negatively correlated with the minimum oxygen levels measured in August and September the previous year; this negative correlation was significant $(p<0.05)$ for lymphocystis in September, while not for epidermal papilloma $(p<0.1)$. The prevalence of lymphocystis and epidermal papilloma was significantly correlated $(p<0.01)$. No significant correlation was observed between stock density (expressed as catch per unit effort) and the diseases in question. It is probably the stress caused by the oxygen deficiency - especially the sublethal levels - that triggered the outbreak of the 2 viral diseases lymphocystis and epidermal papilloma.
\end{abstract}

KEY WORDS: Oxygen deficiency $\cdot$ Dab $\cdot$ Lymphocystis - Epidermal hyperplasia/papilloma $\cdot$ Skin ulceration Epidemiology

\section{INTRODUCTION}

The occurrence of diseases in wild fish stocks is not a new phenomenon. Most of the lesions observed in flatfish today, during fish disease surveys, had already been described at the beginning of this century (Johnstone 1905, 1925). However, the prevalence of the diseases was not registered at that time

The close relationship between environmental stress and the outbreak of fish diseases has been widely accepted since the early 1970s (Wedemeyer 1970, Snieszko 1974), and since then a series of investigations into the impact of pollution on diseases in natural fish stocks have been conducted. The first considerations and results of work on the monitoring of the biological effects of marine pollution were summarized by McIntyre \& Pearce (1980).
In the following years, a series of studies were carried out in many countries, especially in those bordering the North Sea and in the USA (Christensen 1980 Dethlefsen 1980, 1984, Möller 1981, Despres-Patanjo et al. 1982, Dethlefsen \& Watermann 1982, Mellergaard \& Nielsen 1984, 1985, Vethaak 1991, 1992, 1993). However, most of the work done in this field has been concerned with short-term investigations in relatively restricted areas (McArdle et al. 1982, Bucke et al. 1983, Möller 1984, Bucke \& Nicholson 1987).

Long-term disease investigations are needed to assess the impact of temporal and spatial variations of environmental parameters on the disease status of fish stocks. Such investigations of the abundance and the dynamics of fish diseases covering large sea areas have been reported by Dethlefsen et al. (1987) and Dethlefsen (1990), who covered most of the North Sea 
in the periods 1979 to 1986 and 1979 to 1989 , respectively, by Banning (1987), who concentrated on the southeastern part of the North Sea in the period 1981 to 1985 and by Mellergaard \& Nielsen (1990), who dealt with the Danish coastal zones.

The present work describes a long-term study of the epidemiology of selected externally visible skin lesions on dab in an area of the southern Kattegat, and the possible association of the prevalence of the lesions with oxygen deficiency during the investigation period. Other parameters that might be of importance as stress factors are also included.

\section{MATERIAL AND METHODS}

Fish sampling. Common dab Limanda limanda L. were sampled annually in May from 1984 to 1993 on board the RV 'Dana' using a standard fishing trawl, a Nymplex fishing trawl, Star model. The trawl was either rigged with $12^{\prime \prime}(30 \mathrm{~cm})$ rubber discs or with $10^{\prime \prime}$ (25 cm) bobbins on the foot rope, depending on the bottom conditions in the area of research, and fitted with a foot rope chain. The stretched mesh size in the cod end was $40 \mathrm{~mm}$. Fishing took place at a number of sites where trawl tracks had been available from commercial fishermen. The present work deals with data obtained from 4 sites which were severely affected by oxygen deficiency in autumn 1986 and 1988 (Fig. 1). Standard $1 \mathrm{~h}$ hauls were taken at a speed of 3 knots. One or two hauls were taken at each station.

Handling of the sample. The total catch was sorted into species and the dab were subjected to further investigation. A sample of 150 to 250 specimens (a sample size required for the detection of a prevalence of at least $2 \%$ with $95 \%$ confidence; Martin et al. 1987) was examined, corresponding to 15 to $20 \mathrm{~kg}$ per haul. Subsamples were taken at random if the total weight of dab exceeded $20 \mathrm{~kg}$. For all fish examined, the length, weight, sex and health status were registered. After recording the disease, the otoliths from the first 96 fish were removed for ageing later in the laboratory.

Selection of gross lesions. The dab were examined for the presence of the diseases lymphocystis, epidermal hyperplasia/papilloma and skin ulcers using recommended detection procedures (Anon 1989). These diseases have been well described in literature (Möller \& Anders 1983, Bucke et al. 1995) in terms of their gross appearance and aetiology.

Lymphocystis (Fig. 2): A viral disease, recognized by the presence of creamy white, occasionally pigmented nodules up to $1 \mathrm{~mm}$ in diameter situated in the skin (dermis) of the fins and the body. The criterion for recording was the presence of more than 1 surface nodule.

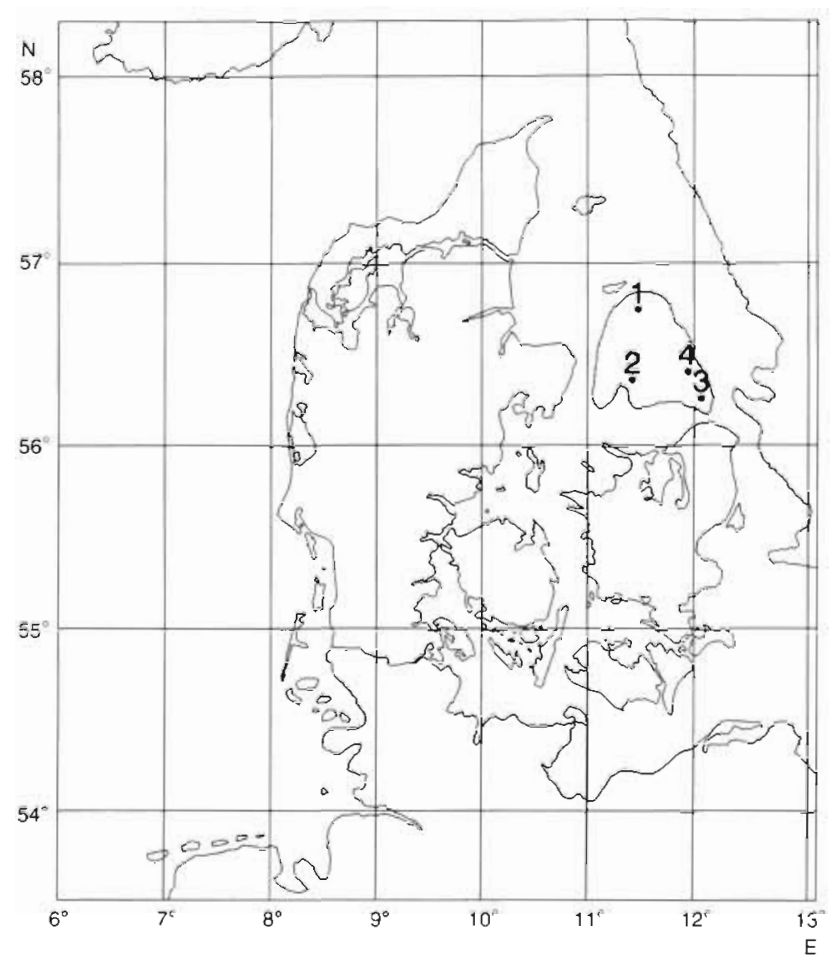

Fig. 1. Location of the 4 sites within the area (dotted) affected by oxygen deficiency in the southern Kattegat

Epidermal hyperplasia/papilloma (Fig. 3): Hyperplasias were recognized as slightly elevated, smooth, opalescent to creamy white areas in contrast to the papillomas which were more elevated, gray to creamy white areas with irregular surface often showing haemorrhages. In some cases, they appeared darkly pigmented. In the present work, epidermal hyperplasias and papillomas are both designated 'epidermal papillomas'. The aetiology is probably viral (Bloch et al. 1986). The criterion for recording was 1 or more lesions larger than $2 \mathrm{~mm}$ in diameter.

Skin ulcerations (Fig. 4): Usually irregular rounded lesions which, if infected by bacteria, appear haemorrhagic. In the process of healing, the periphery becomes pigmented. The aetiology is probably primary traumatic skin damage followed by a secondary infection by bacteria (Mellergaard \& Nielsen 1990). The criterion for recording was 1 or more open lesions.

Macroscopic inspection. Prior to external inspection the fish were rinsed with sea water. Both sides of the fish were carefully examined visually and by palpation and the fins were spread and lifted. The examination took place under a strong light source.

In order to obtain the highest degree of precision in diagnosing the diseases, only 1 person conducted the registration during the whole period of investigation. The otoliths were read by 2 skilled persons. 
Fig. 2. Limanda limanda. Lymphocystis. Clusters of nodules on the fins typical of lymphocystis

Fig. 3. Limanda limanda. Epidermal hyperplasia/papilloma. Multiple epidermal papilloma on the pigmented side of a dab

Fig. 4. Limanda limanda. Skin ulcer. Typical abrasion-like ulceration
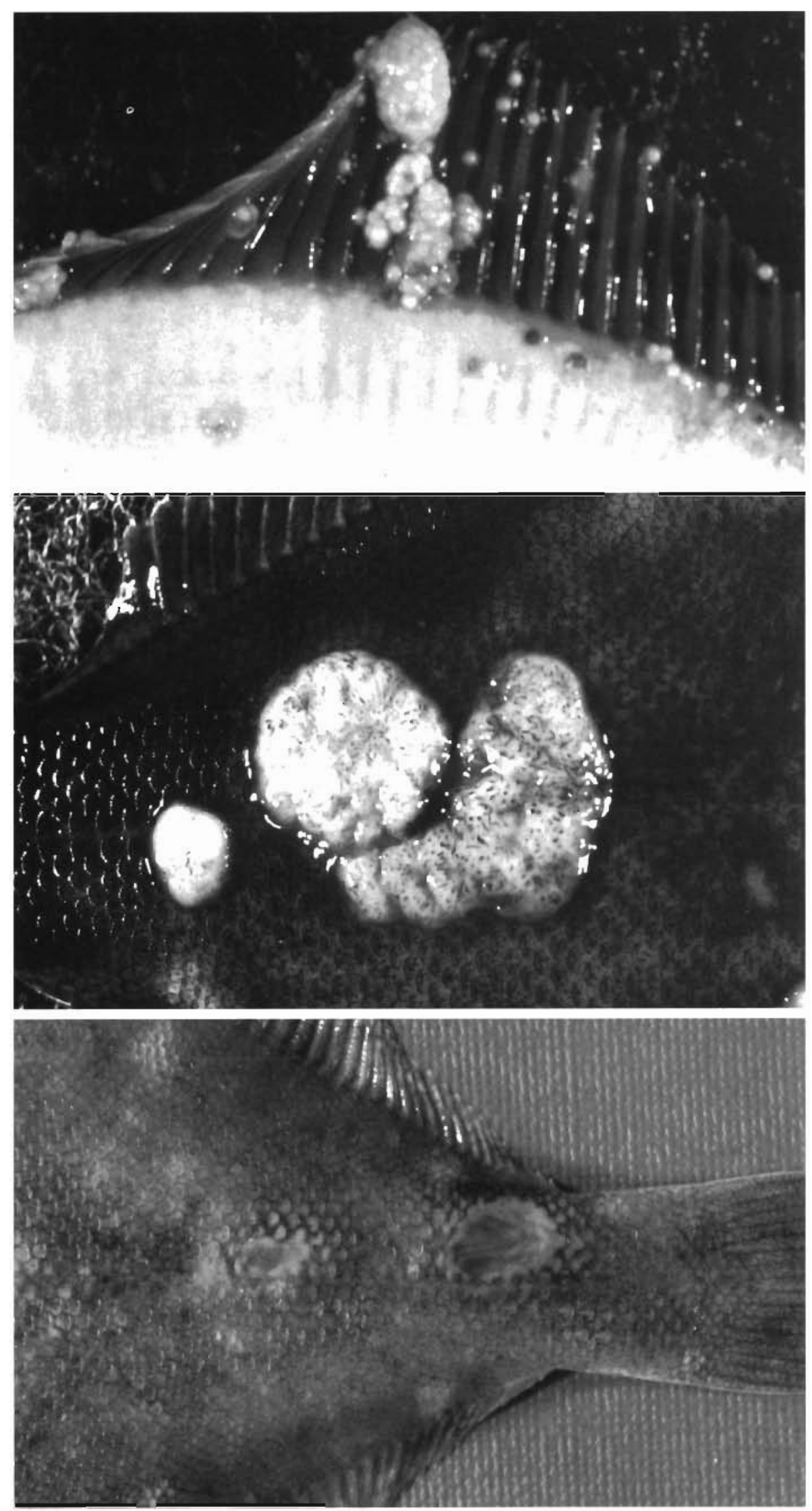
Data analysis. Most of the data analysis was carried out using the public domain software 'Epi-Info' version 5.0 (Dean et al. 1990). The strength of association between a factor and a disease is known as the relative risk $(R R)$. The $R R$ is calculated as the ratio between the disease rate in an 'exposed' group and the disease rate in an 'unexposed' group. All $R R$ estimations are presented with $95 \%$ confidence intervals. Stratified analysis was carried out for the factors site, sex and age (age 3 to $6 \mathrm{yr}$, as these were the predominant groups). The Mantel-Haenszel summary $R R$, which is a weighted average of the separate $R R$, was calculated for all strata to control confounding. The proportion of the disease in the 'exposed group' due to a certain exposure, e.g. oxygen deficiency, is called the attributable fraction

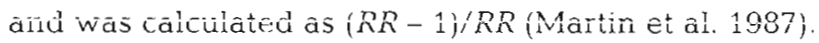

Data on disease rates are not normally distributed. Therefore, the nonparametric Wilcoxon signed rank test was used for testing differences of the mean between paired data, Kruskal-Wallis 1-way ANOVA for testing differences of the mean of several groups and Spearman rank correlation test for testing correlation between different variables.

As severe oxygen deficiency first occurred during late summer and early autumn 1986, the disease data from the period 1984 to 1986 should be unaffected by the oxygen depletion, since these were sampled in
May. As the RR of lymphocystis and epidermal papilloma in 1984 to 1986 did not demonstrate any statistical difference between years, all data from this period were used for characterising the 'unexposed' group (i.e. reference group) of lymphocystis and epidermal papilloma, respectively. As the data on skin ulcers were limited, only selected statistical analysis was conducted for this lesion.

The condition factor $\left[100 \times\right.$ weight $(g) \times$ length $^{-3}$ $(\mathrm{cm})$ ] was calculated based on the total weight of individual fish (in contrast to ungutted weight as recommended in Anon 1989).

Oxygen data. Data on the oxygen concentrations in the area in August and September were obtained from the ICES Hydrographic Service, ICES Headquarters, Copenhagen, Denmark.

\section{RESULTS}

\section{Catch data}

All data presented were sampled at 4 stations situated within the oxygen-depleted area (Fig. 1). A total of $11298 \mathrm{dab}$ were examined during this investigation. Table 1 lists the number of dab inspected each year for externally visible diseases according to sex, site and

Table 1. Limanda limanda. Number of dab inspected for externally visible diseases according to sex, site and age

\begin{tabular}{|c|c|c|c|c|c|c|c|c|c|c|}
\hline \multirow[t]{2}{*}{ Year } & \multicolumn{2}{|c|}{ Sex } & \multicolumn{4}{|c|}{ Site } & \multicolumn{4}{|c|}{ Age $^{a}$} \\
\hline & Male & Female & 1 & 2 & 3 & 4 & 3 & 4 & 5 & 6 \\
\hline 1984 & 338 & 264 & 218 & 384 & - & - & 146 & 196 & 117 & 22 \\
\hline 1985 & 602 & 650 & 256 & 376 & 406 & 214 & 221 & 207 & 134 & 46 \\
\hline 1986 & 550 & 490 & 341 & 213 & 326 & 160 & 95 & 115 & 94 & 34 \\
\hline 1987 & 440 & 387 & 263 & 309 & 156 & 99 & 320 & 102 & 20 & 1 \\
\hline 1988 & 415 & 404 & 158 & 398 & 206 & 57 & 156 & 139 & 42 & 8 \\
\hline 1989 & 475 & 509 & 234 & 411 & 215 & 124 & 150 & 180 & 94 & 17 \\
\hline 1990 & 526 & 481 & 269 & 458 & 186 & 94 & 134 & 149 & 71 & 12 \\
\hline 1991 & 693 & 644 & 475 & 346 & 246 & 270 & 157 & 164 & 104 & 24 \\
\hline 1992 & 741 & 689 & 383 & 564 & 215 & 268 & 144 & 156 & 48 & 8 \\
\hline 1993 & 1101 & 900 & 749 & 764 & 386 & 102 & 207 & 237 & 68 & 25 \\
\hline Total & 5887 & 5418 & 3346 & 4223 & 2342 & 1388 & 1730 & 1645 & 792 & 197 \\
\hline
\end{tabular}

Table 2. Limanda limanda. Total number of fish examined and fish affected by the 3 diseases investigated

\begin{tabular}{|lrrrrrrrrrr|}
\hline & 1984 & 1985 & 1986 & 1987 & 1988 & 1989 & 1990 & 1991 & 1992 & 1993 \\
\hline Total number examined & 602 & 1252 & 1040 & 827 & 819 & 984 & 1007 & 1337 & 1429 & 2001 \\
Lymphocystis & 24 & 38 & 45 & 56 & 117 & 145 & 112 & 86 & 62 & 114 \\
Epidermal papilloma & 7 & 11 & 15 & 22 & 23 & 32 & 27 & 16 & 21 & 16 \\
Skin ulcers & 0 & 3 & 4 & 2 & 0 & 6 & 2 & 0 & 2 & 0 \\
\end{tabular}


age. In some cases, it was not possible to obtain the minimum sample size but as the data in most of the calculations were pooled for all stations within the affected area, these results were included. The number of aged fish is less than the total number examined because otoliths were only removed from a subsample of $96 \mathrm{dab}$ from each haul. In Table 2, the total number of fish examined and the number of fish affected by each of the 3 diseases are listed for each year.

\section{Disease examination}

$$
\text { Lymphocystis }
$$

From 1984 to 1986 the prevalence of lymphocystis was 3 to $4 \%$ (Fig. 5). In 1987, this increased to $6.8 \%$. This trend continued and peaked in 1989 with a prevalence of $14.7 \%$. From 1990, the prevalence started to decrease and reached 4 to $6 \%$ in 1992-93

In the period 1984 to 1986 , the $R R$ for contracting lymphocystis should be 1.0 , as this was chosen as the 'unexposed' group, not having been exposed to oxygen deficiency. However, to demonstrate the annual variation within this period, the data from 1984 to 1986 are presented in the same way as the rest of the data set (Fig 6). If the lowest value of the confidence level is more than 1.0 , the result is significantly ( $\mathrm{p}<0.05$ ) higher than the reference (unexposed) group. The $R R$ in 1984 to 1986 was approximately 1. From 1987, a significant increase of $R R$ to between 1.5 and 4 was observed, and this increase continued for the following 2 years, peaking in 1989 with an $R R$ of contracting lymphocystis of 4 compared to the period 1984 to 1986 . In 1990, a decline started but both the 1990 and 1991 figures were significantly higher than in the 'unexposed' period 1984 to 1986 . The 1992 data reached the same level as the reference period while the $R R$ in 1993 was just above the significance level.

Analysis of the $R R$ of lymphocystis stratified by sites (Fig. 7) showed that for the years 1988 to 1990, the $R R$ was significantly higher than in the 'unexposed' period for Sites 1 to 3 while for Site 4 , the RR became significantly higher from 1987 to 1991. In addition, Site 1 demonstrated a significant increase in 1993. The Mantel-Haenszel weighted $R R$ adjusted for sites demonstrated similar values as for the crude $R R$. Hence, the sites do not act as a confounding factor. Kruskal-Wallis 1-way ANOVA did not show significant difference in the annual variations of the $R R$ among sites.

Analysis of the $R R$ of lymphocystis stratified by sex (Fig. 8) demonstrated that the $R R$ in male dab became significantly higher in 1987 than in 1984 to 1986 and remained significant until 1991, and became significant again in 1993. In contrast, the $R R$ in female dab

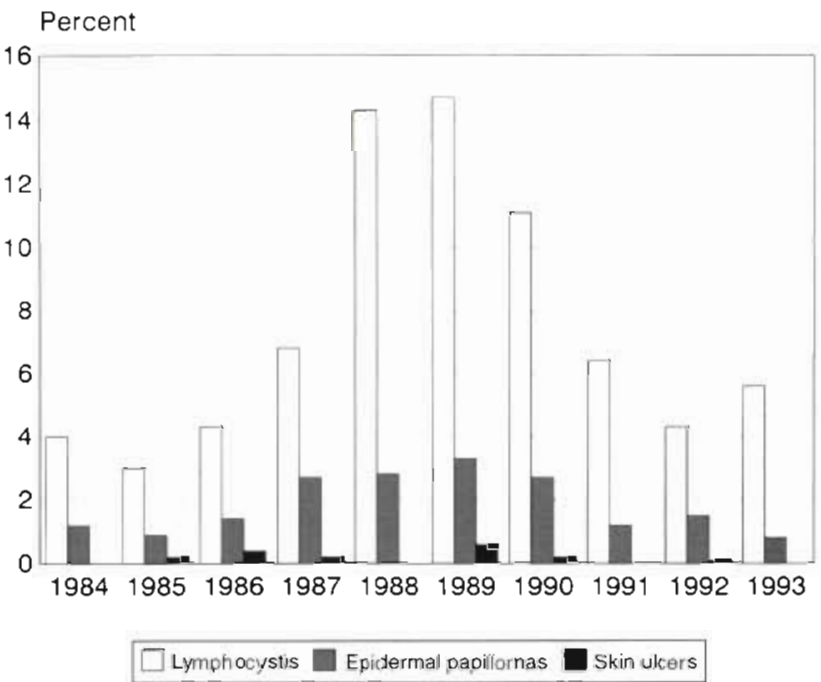

Fig. 5. Limanda limanda. Annual prevalence of lymphocystis, epidermal papilloma and skin ulcers

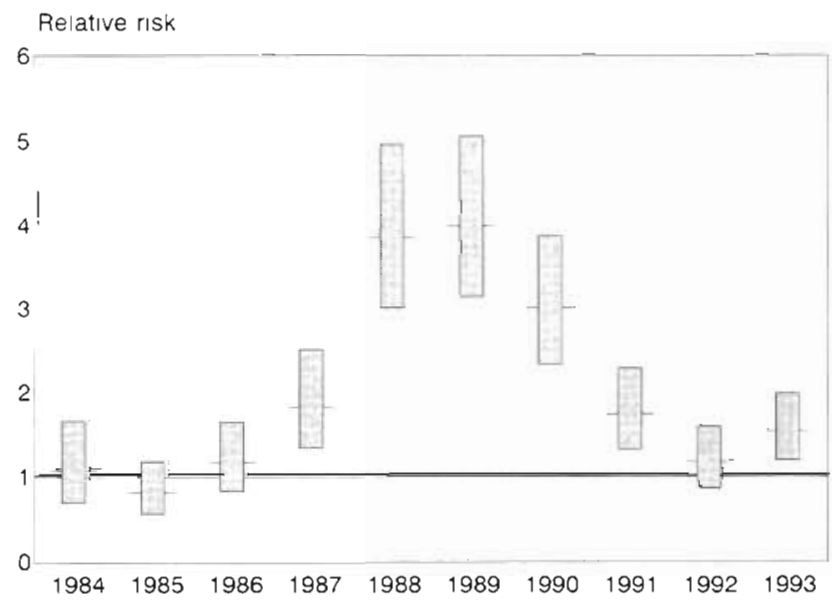

Fig. 6. Limanda limanda. Crude relative risk for lymphocystis presented with $95 \%$ confidence intervals (bar). Where bars are above 1 (bold line) the figures are significantly different from the 1984 to 1986 figures

did not reach significantly higher levels than those in 1984-86 until 1988, and only remained significant until 1990. The Mantel-Haenszel weighted $R R$ adjusted for sex revealed similar values as for the crude $R R$, indicating that sex does not act as a confounding factor for lymphocystis. The $R R$ for females contracting lymphocystis compared with males was 1.04 . Wilcoxon signed rank test did not demonstrate a significant difference in the $R R$ between males and females.

Analysis of the $R R$ of lymphocystis stratified by age (Fig. 9) showed that the RR for 3 yr old dab increased significantly in 1987 compared to 1984 to 1986 , and 

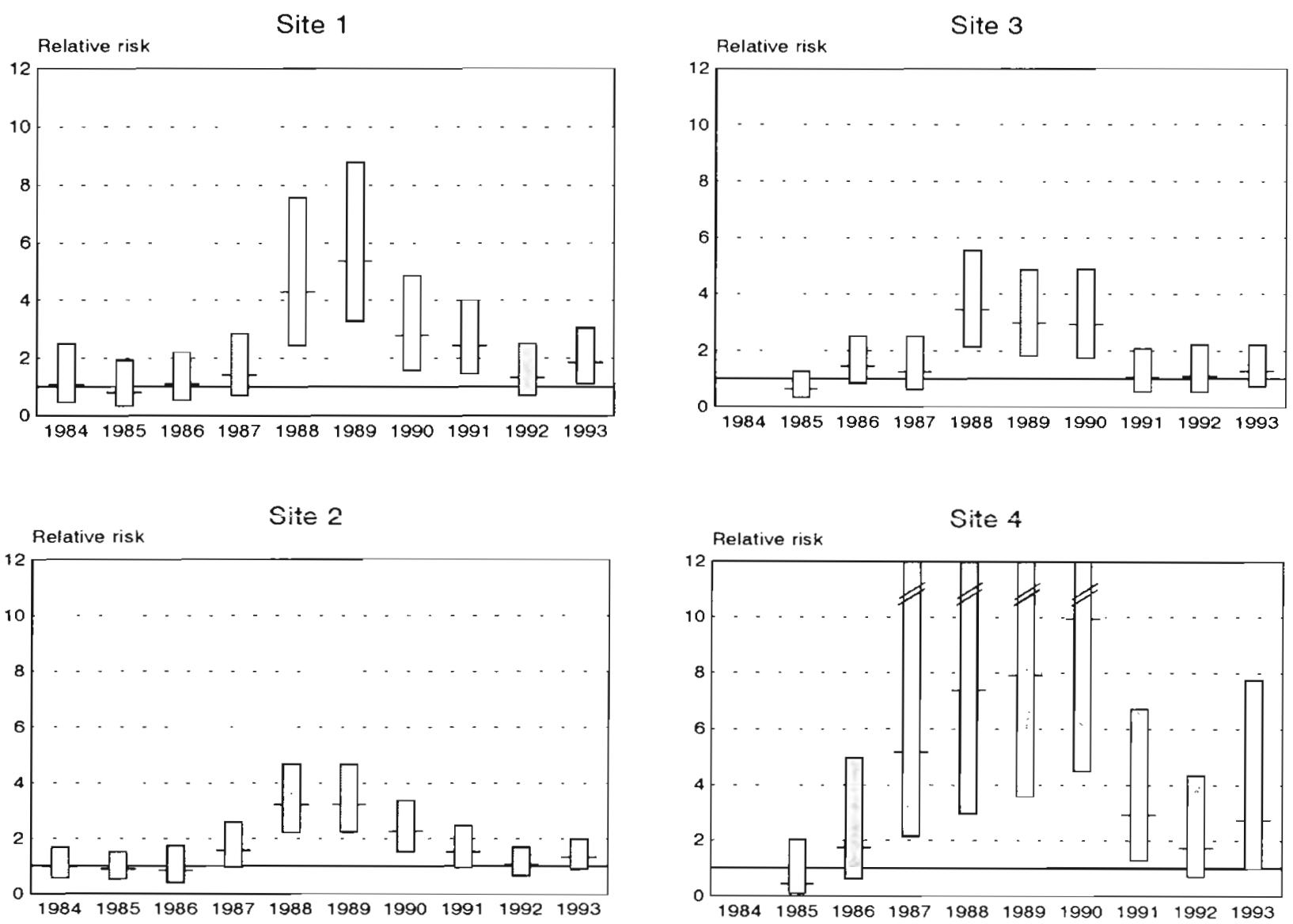

Fig. 7. Limanda Limanda. Relative risk for lymphocystis stratified by sites

remained significant until 1992. The $R R$ for lymphocystis for 4 yr old dab became significantly higher in the period 1988 to 1990 and for the 5 yr old age group levels were only significant in 1989 and 1990. Six yr old fish showed significant levels in the period 1988 to 1990. The Mantel-Haenszel weighted $R R$ adjusted for age revealed similar values as for the crude $R R$, indicating that age is not a confounding factor for lymphocystis. Kruskal-Wallis 1-way ANOVA demonstrated no statistically significant difference in the annual variation of the $R R$ among the age groups.

As demonstrated in Table 3, the attributable fraction of lymphocystis, which was the estimated increase in the disease rate due to oxygen deficiency, amounted to $45 \%$ in 1987 , increasing to $75 \%$ in 1989 . After this, a decline was observed.

\section{Epidermal papilloma}

The prevalence of epidermal papilloma varied from 0.9 to $1.4 \%$ in the period 1984 to 1986 (Fig. 5). In 1987 . an increase was observed and this increase peaked in 1989 with a prevalence of $3.3 \%$. From 1990, a decline began and the starting level was reached in 1991. In the period 1991 to 1993 the prevalence varied between 0.8 and $1.5 \%$.

The $R R$ data for epidermal papilloma are presented in the same way as for lymphocystis (Fig. 10). The $R R$ for 1984 to 1986 was approximately 1 . A significant increase in the $R R$ to a level between 2 and 3 was observed from 1987 to 1990 , with a peak of 3.3 in 1989. However, the $R R$ for the period 1991 to 1993 corresponded to the initial level.

Table 3. Limanda limanda. Attributable fraction for lymphocystis and epidermal papilloma for the period 1987 to 1993

\begin{tabular}{|lrrrrrrrr}
\hline & 1987 & 1988 & 1989 & 1990 & 1991 & 1992 & 1993 \\
\hline Lymphocystis & 0.454 & 0.741 & 0.749 & 0.668 & 0.425 & 0.146 & 0.351 \\
Epidermal papilloma & 0.571 & 0.594 & 0.649 & 0.575 & 0.047 & 0.224 & -0.426 \\
\hline
\end{tabular}



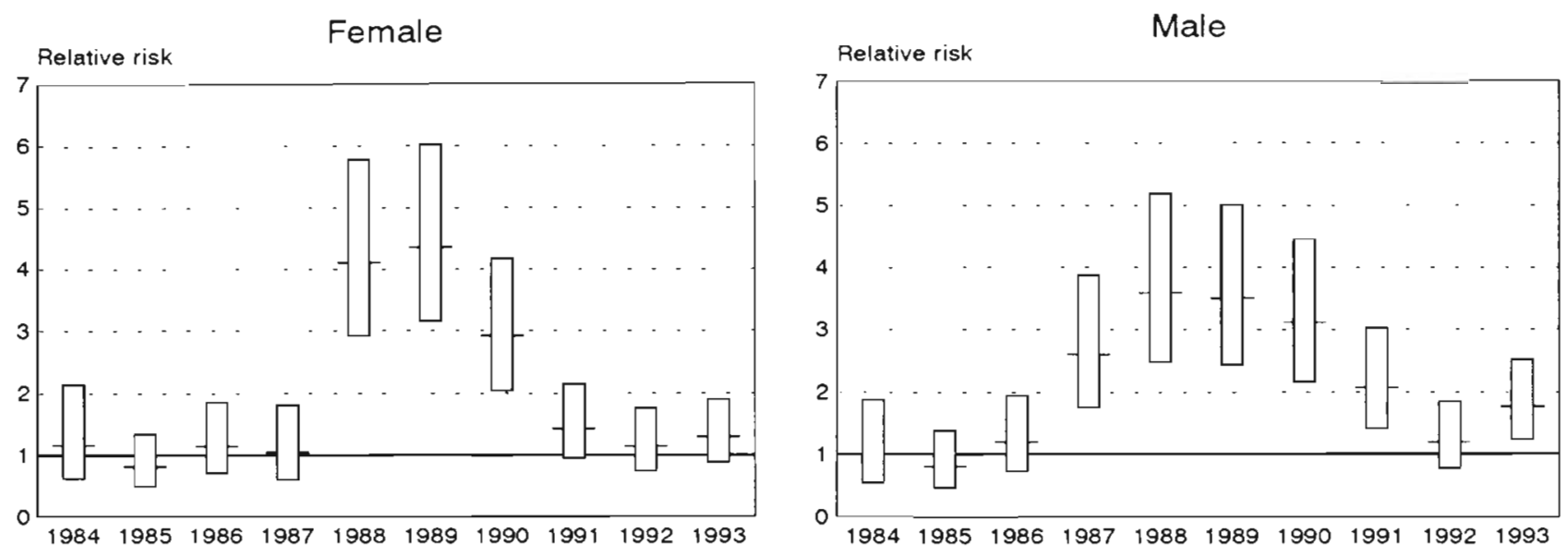

Fig. 8. Limanda limanda. Relative risk for lymphocystis stratified by sex

Analysis of the $R R$ of epidermal papilloma stratified by sites (Fig. 11) showed that significant increases occurred only at Sites 1 and 3. At Site 1, a significant increase in the $R R$ was observed in 1987 to 1990 and again in 1992. At Site 3, a significant increase of the $R R$ was observed in 1987, 1989 and 1990. However, Sites 2 and 4 showed similar trends in the $R R$, although the changes from the reference period 1984 to 1986 were not statistically significant. The Mantel-Haenszel weighted $R R$ adjusted for sites revealed similar values as for the crude $R R$, indicating that sites did not act as a confounding factor Because the number of affected
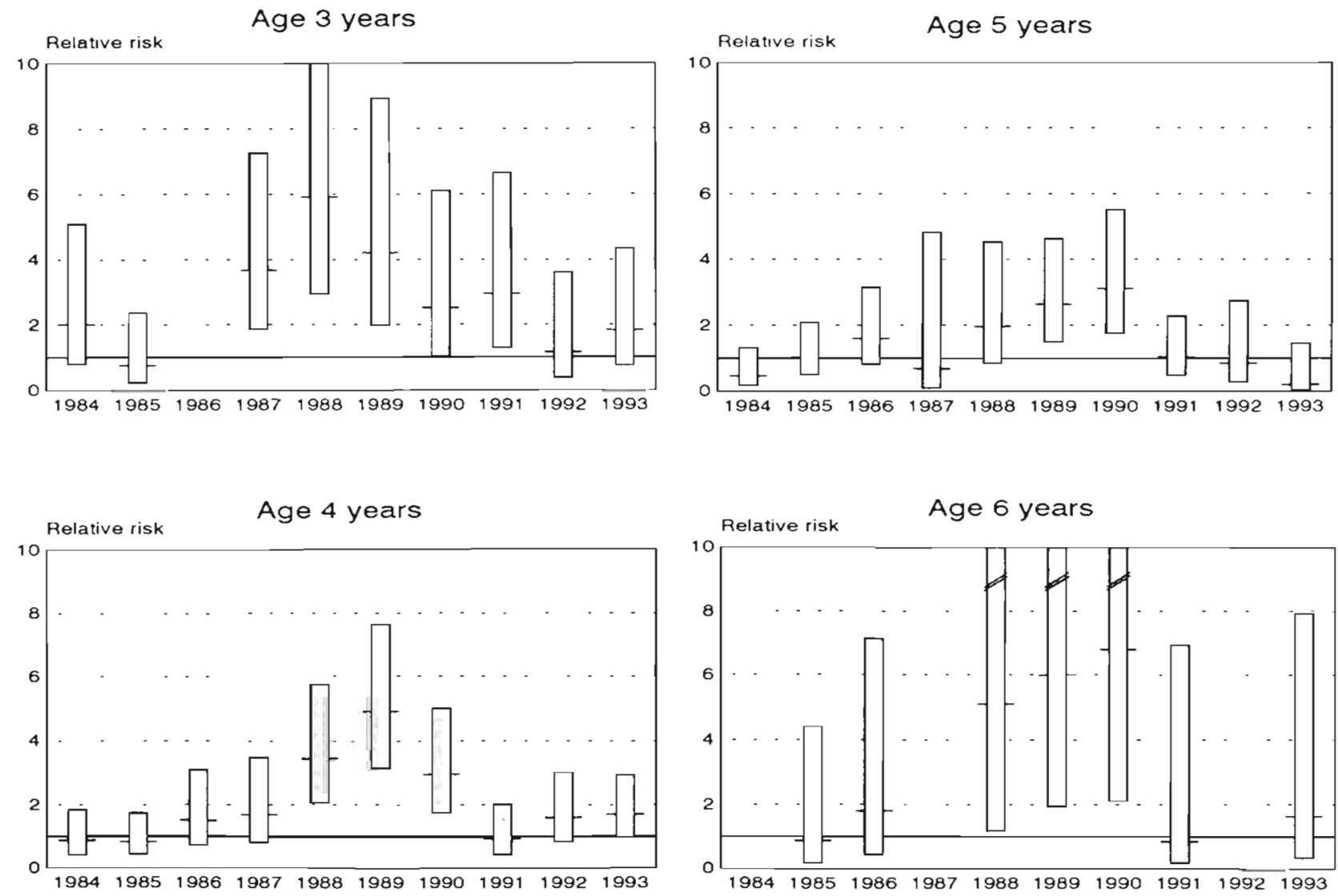

Fig. 9. Limanda limanda. Relative risk for lymphocystis stratified by age 


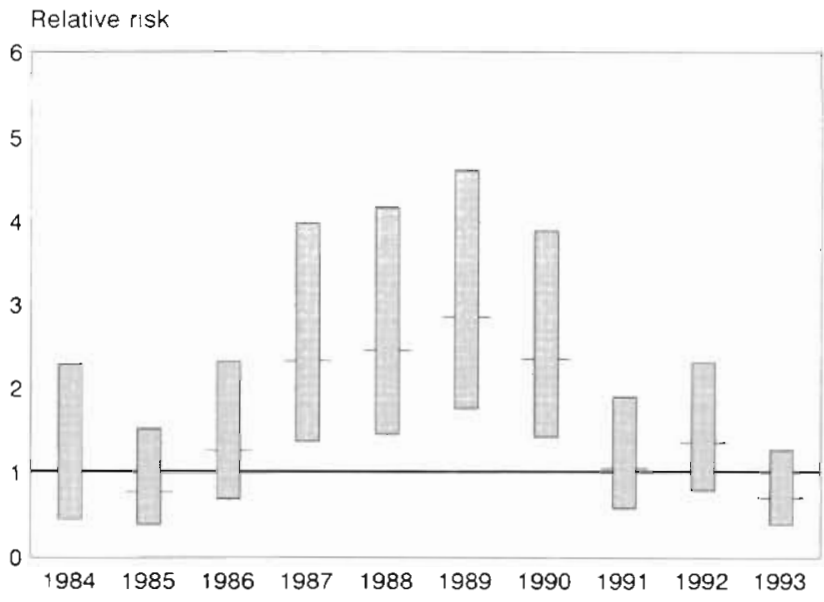

Fig. 10. Limanda limanda. Crude relative risk for epidermal papilloma presented with $95 \%$ confidence intervals (bar). Where bars are above 1 (bold line) the figures are significantly different from the 1984 to 1986 figures

fish was limited, the confidence level of some of the values was very broad. Kruskal-Wallis 1-way ANOVA did not show a significant difference in the annual variations of the $R R$ among sites.

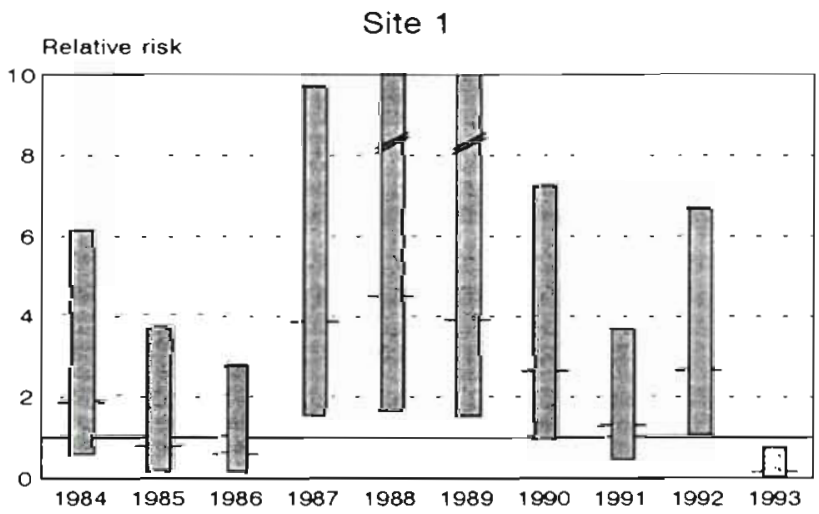

The $R R$ of epidermal papilloma stratified into females and males (Fig. 12) showed that the $R R$ in females became statistically significant from 1987 to 1990, after which it reached the original level. In contrast to the females, the $R R$ of the males became significantly higher than in the 'unexposed' period only in 1989. However, the crude $R R$ did not differ from the Mantel-Haenszel weighted $R R$ adjusted for sex, indicating that this factor is not to be regarded as a confounder. For females the $R R$ of contracting epidermal papilloma was significantly higher $(p<0.001)$ than for males, namely 2.8 . The Wilcoxon signed rank test did not demonstrate a significant difference in the annual variation of the $R R$ between males and females.

Stratification of the $R R$ into age groups (Fig. 13) demonstrated significantly clcvatcd RRS only for 3 and 5 yr old fish. For the 3 yr age group, the $R R$ in 1987 and 1988 was significantly higher than for the 'unexposed' period while for the 5 yr age group only the $R R$ for 1989 became significant. Also in this case, the confidence levels were broad for some of the values because of the limited number of affected dab. The Mantel-Haenszel weighted $R R$ adjusted for age revealed similar values as for the crude $R R$, indicating that age is not a con-
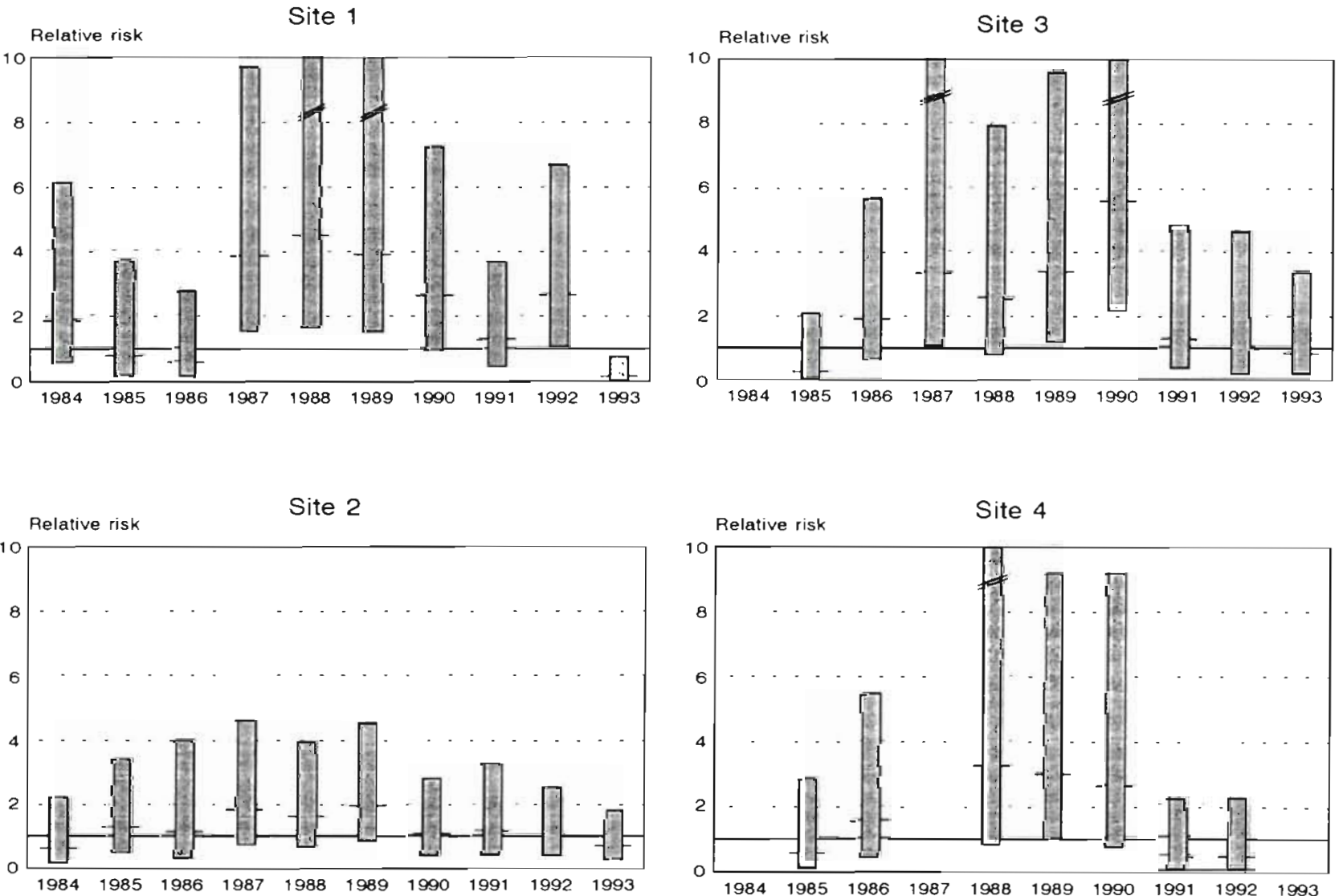

Fig. 11. Limanda limanda. Relative risk for epidermal papilloma stratified by sites 
Female

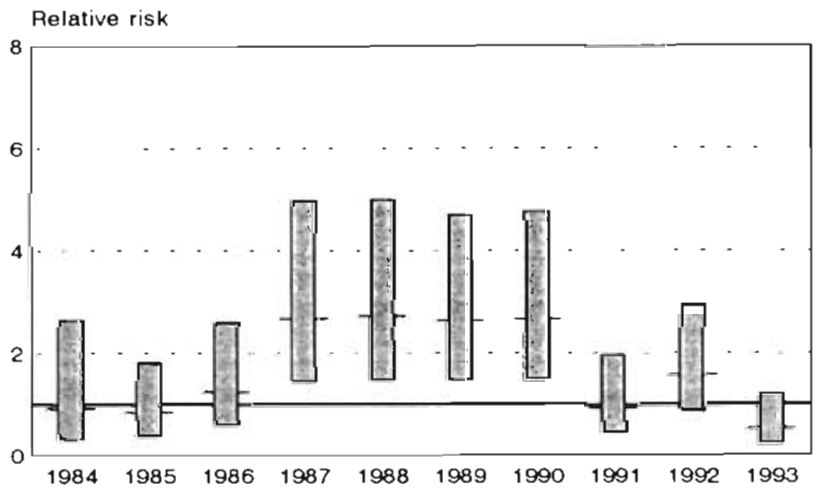

Male

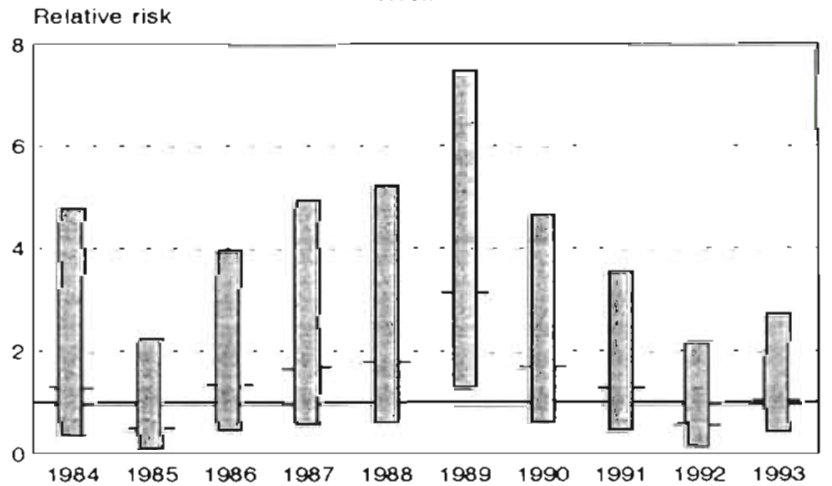

Fig. 12. Limanda limanda. Relative risk for epidermal papilloma stratified by sex

founding factor for epidermal papilloma. KruskalWallis 1-way ANOVA demonstrated no statistically significant difference of the annual variation of the $R R$ among age groups.

As shown in Table 3, the attributable fraction of epidermal papilloma amounted to $57 \%$ in 1987, increasing to $65 \%$ in 1989. From 1990, a decline was observed.
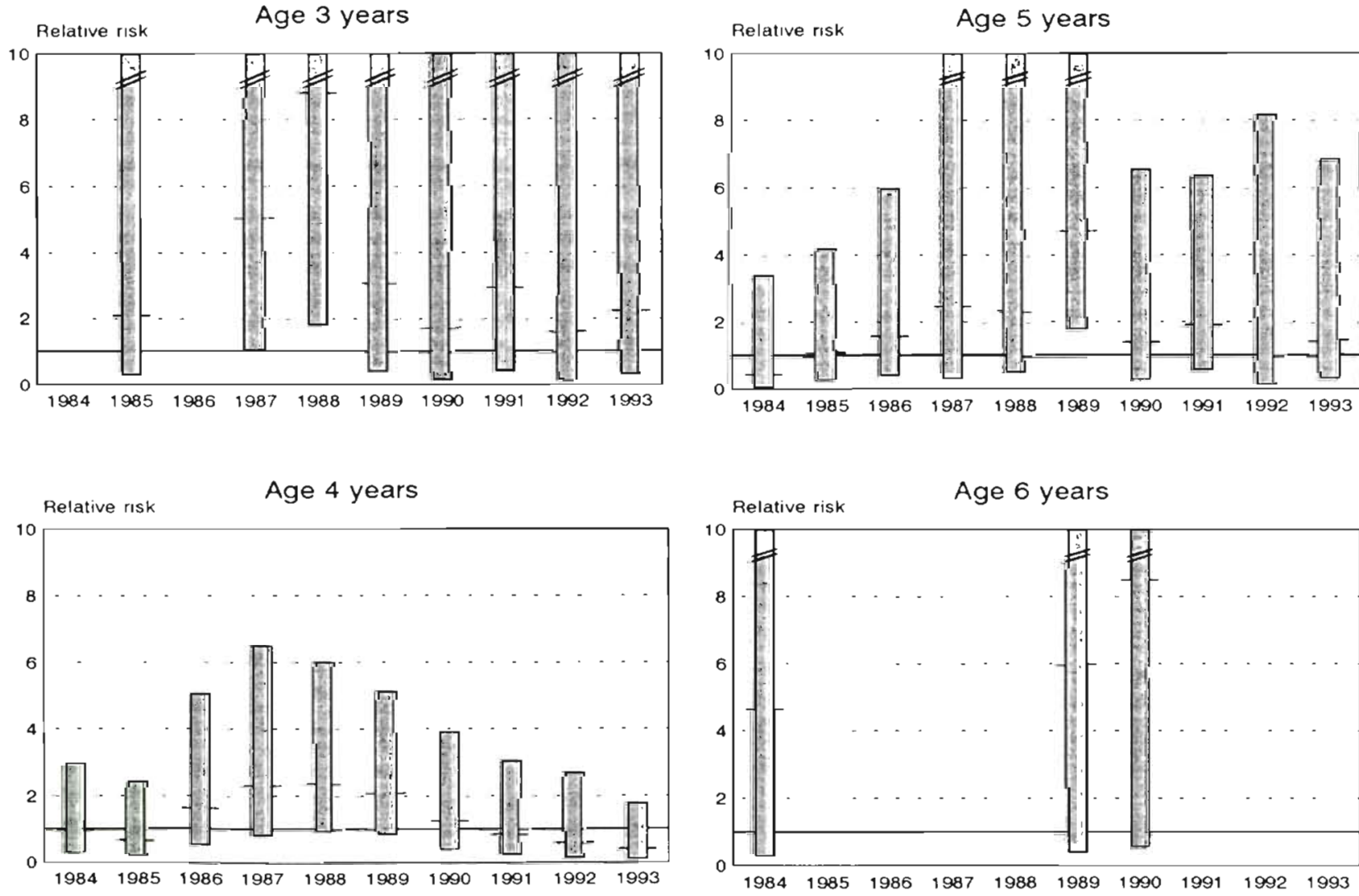

Fig. 13. Limanda limanda. Relative risk for epidermal papilloma stratified by age 


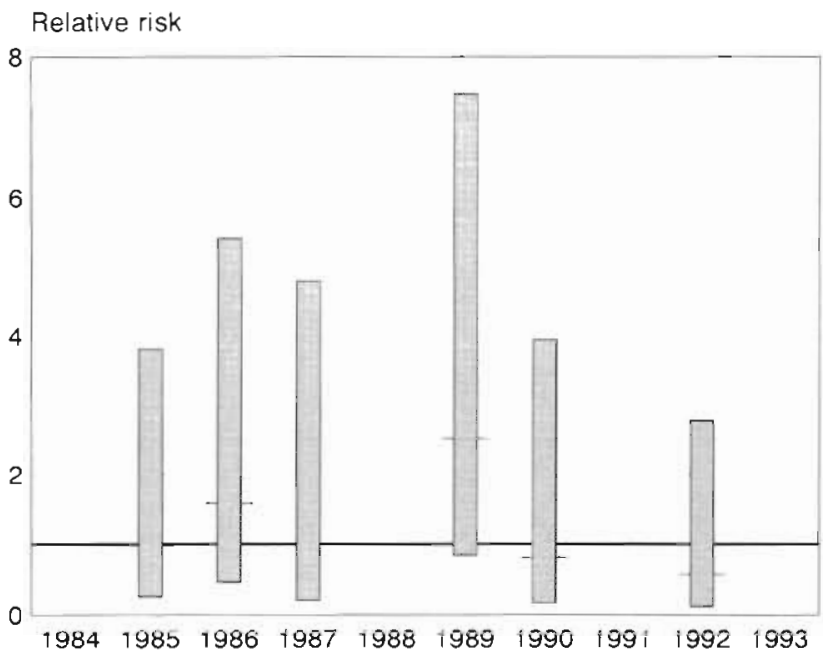

Fig. 14. Limanda limanda. Crude relative risk for skin ulcers

Skin ulcers occurred more frequently in female than in male dab. The $R R$ of females contracting skin ulcers compared to males was 3.74 , a statistically significant difference $(p<0.01)$

\section{Correlations}

Diseases

The Spearman rank correlation test demonstrated a statistically significant positive correlation $(p<0.01)$ between the prevalences of lymphocystis and epidermal papilloma for the period 1984 to 1993, while skin ulcers correlated significantly neither with lymphocystis nor epidermal papilloma.
Diseases and stock density

The catch per unit effort (CPUE), i.e. the number of dab per hour of trawl time for the area, is illustrated in Table 4 . The stock density was calculated on the basis of the approximate area fished during $1 \mathrm{~h}$ of trawl tow and was within the range 2 to 21 dabs per $1000 \mathrm{~m}^{2}$. The Spearman rank correlation test did not show a statistically significant correlation between the prevalence of any of the diseases and the stock density in the period 1984 to 1993.

\section{Diseases and condition factor}

Evaluation of an eventual correlation between the mean condition factor of the dab population (Table 4) and the prevalence of the different diseases was conducted using the Spearman rank correlation test, and did not show any significant correlation.

\section{Diseases and oxygen deficiency}

The test for correlations between diseases and oxygen deficiency was conducted by comparing the prevalence of the different diseases in a year with the mean and minimum oxygen levels measured in August and September the previous year (Table 5), as it was expected that low oxygen levels in the autumn might affect the disease level the following year. The Spearman rank correlation test demonstrated a negative correlation between the different diseases and oxygen level. A statistically significant correlation $(\mathrm{p}<$ $0.05)$ was demonstrated for lymphocystis and the minimum oxygen levels in September, while the signifi-

Table 4. Limanda limanda. Catch per unit effort ( $f i s h \mathrm{~h}^{-1}$ ) and mean condition factor for dab for the period 1984 to 1993

\begin{tabular}{|lcccccccccc}
\hline & 1984 & 1985 & 1986 & 1987 & 1988 & 1989 & 1990 & 1991 & 1992 & 1993 \\
\hline Catch per unit effort & 778 & 343 & 370 & 797 & 1619 & 2443 & 421 & 3263 & 2614 & 2200 \\
Mean condition factor & 0.973 & 0.992 & 0.976 & 0.986 & 0.959 & 0.992 & 0.984 & 0.995 & 0.969 & 0.953 \\
\hline
\end{tabular}

Table 5. Mean and minimum oxygen levels $\left(\mathrm{ml} \mathrm{l}^{-1}\right)$ for August and September in the oxygen-depleted area of the Kattegat for the period 1983 to 1992

\begin{tabular}{|llllllllllll|}
\hline & & 1983 & 1984 & 1985 & 1986 & 1987 & 1988 & 1989 & 1990 & 1991 & 1992 \\
\hline August & Mean & 2.75 & 3.44 & 3.86 & 3.26 & 3.66 & 3.03 & 2.72 & 2.79 & 2.79 & 3.68 \\
& Minimum & 2.46 & 3.36 & 3.54 & 3.16 & 3.15 & 1.79 & 2.50 & 2.39 & 2.42 & 2.91 \\
September & Mean & 2.93 & 2.71 & 3.76 & 2.15 & 3.03 & 1.29 & 2.85 & 1.72 & 2.27 & 2.47 \\
& Minimum & 2.55 & 2.55 & 2.13 & 0.95 & 1.81 & 0.46 & 1.67 & 1.35 & 1.69 & 1.78 \\
\hline
\end{tabular}


cance levels for the similar correlation for epidermal papilloma and for ulcers were $\mathrm{p}<0.1$ and $\mathrm{p}<0.5$ respectively.

\section{DISCUSSION}

The present study demonstrated that oxygen deficiency may trigger the outbreak of endemic fish diseases such as lymphocystis and epidermal papilloma while the prevalence of skin ulcers was found to be unaffected. The occurrence of oxygen deficiency in the southern Kattegat has been caused by increasing eutrophication problems up through the 1970 s and the early 1980s (Kronvang et al. 1993). Physical (density stratification) and chemical (increasing nutrient levels) conditions in the water body resulted in the occurrence of severe oxygen deficiency in the bottom water in August and September from 1986 to 1988 (Hansen et al. 1995).

The importance of environmental stress in the dynamics of fish diseases is well known (Fry 1969, Wedemeyer 1970, Snieszko 1974). In aquaculture, outbreaks of bacterial diseases in fish species induced by oxygen deficiency have been described previously (Wedemeyer 1981). However, disease outbreaks in wild fish stocks have been associated only in a very few cases with oxygen deficiency. From fresh water, Haley et al. (1967) described an Aeromonas liquefaciens epizootic event in American shad Alosa sapidissima and threadfin shad Dorosoma petenense, probably triggered by the very low dissolved oxygen content in the water of a river basin due to organic pollution. Mellergaard \& Nielsen (1987) reported on the correlation between oxygen deficiency in certain areas of the eastern North Sea and increased disease prevalence in dab. These observation were confirmed by Dethlefsen (1990). The present work is the first study in which the long-term effects of oxygen depletion on the health status of fish have been studied.

Flatfish such as plaice Pleuronectes platessa, flounder Platichthys flesus and common dab have demonstrated the ability to adapt to low oxygen levels (Steffensen et al. 1981, Weber 1993). In the Kattegat, the duration of the periods with oxygen depletion ( 2 to $3 \mathrm{ml}$ $\mathrm{O}_{2} 1^{-1}$ ) in the bottom water was several weeks. So, the fish probably adapted to the low oxygen condition. However, in some instances the oxygen levels were further reduced to lower than $2 \mathrm{ml} \mathrm{O}_{2} \mathrm{l}^{-1}$ (Table 5). Under laboratory conditions dab showed avoidance reactions at oxygen levels of 0.9 to $1.1 \mathrm{ml} \mathrm{l}^{-1}$ (Weber 1993) and such reactions probably took place on some occasions in the sea. However, as the oxygen deficiency covered large areas, many fish were probably unable to escape and, while remaining in the area dur- ing the extreme oxygen deficiency conditions, they were exposed to concentrations close to the lethal oxygen levels which are reported to be 0.4 to $1.3 \mathrm{ml} \mathrm{l}^{-1}$ (Muus 1967, Bagge 1970, Scholz \& Waller 1992, Weber 1993). It is probably the sum of all the stress factors occurring during the oxygen deficiency periods that triggers the disease outbreaks. Of these factors, the sublethal oxygen levels are probably one of the main contributors to the outbreak of lymphocystis and epidermal papilloma, which is indicated by the significant correlation between the minimum oxygen levels in September and lymphocystis and the almost significant correlation $(p<0.1)$ for epidermal papilloma.

Under aquaculture conditions, reduction of growth associated with low oxygen levels has been observed in common carp Cyprinus carpio (Chiba 1965), in largemouth bass Micropteris salmonides (Stewart et al. 1967 ) and in coho salmon Oncorhynchus kisutch as well as chum salmon Oncorhynchus nerka (Brett \& Blackburn 1981). These fish species demonstrated severe reduction in growth at oxygen levels between 2 and $3 \mathrm{ml} \mathrm{l}^{-1}$. This would probably be the case for dab, too. Therefore, it might be expected that long periods of oxygen deficiency might reduce the condition factor of the fish and hence could increase their susceptibility to diseases. However, no correlation between the condition factor and the diseases in question was observed. This finding corresponds with that of Dethlefsen et al. (1987), who did not observe any correlation between the prevalence of lymphocystis and the nutritional status of dab in the southern North Sea. This finding is in contrast to Möller (1981), who found a significant positive correlation between the condition factor and lymphocystis in dab in the southeastern North Sea, and to Vethaak et al. (1992), who found a high prevalence of lymphocystis associated with low condition factor. In the present study, no difference in the condition factor was observed between the period before the severe oxygen deficiency, 1984 to 1986, and the period after, 1987 to 1993. A possible explanation for this is that the benthic fauna are rapidly re-established, as their pelagic larval stages are unaffected by the oxygen depletion at the bottom and they will settle when the oxygen conditions are normalised.

Stock density expressed as CPUE was not found to be significantly correlated with any of the diseases investigated. The low CPUE found in 1990 is probably not a natural phenomenon but is probably a reflection of bad weather conditions during fishery that year. Even if the CPUE for 1990 was elevated to the 1989 level, the correlation between the CPUE and the different diseases did not become statistically significant. However, despite the fact that a statistically significant correlation between stock density and the diseases in question could not be established, high stock density probably 
adds to the stress caused by the oxygen deficiency, as the risk of contracting a disease increases with decreasing distance between individuals (Möller 1985).

The attributable fraction or aetiological fraction represents a quantitative expression of the proportion of disease in the fish stock due to the environmental parameters. It appears that up to $75 \%$ of the lymphocystis cases and $65 \%$ of the epidermal papilloma cases are due to environmental stress factors, in this case mainly oxygen deficiency.

Most of the 19 observed cases of skin ulcers looked like skin abrasions, indicating that the primary cause may be a traumatic injury from fishing gear. If skin ulcers had an infectious, e.g. bacterial, background they would be expected to respond to the impact of stress (Fialey ei ai. 1967). Huweven, conclüsions conncerning the origin of the ulcers cannot be made based on 19 cases. The fact that the occurrence of lymphocystis and epidermal papilloma was significantly correlated and showed an identical response to oxygen deficiency indicates that both may be of similar aetiological origin, probably viral (Weissenberg 1951, Bloch et al. 1986). Dethlefsen et al. (1987) also found significant positive correlation between the 2 diseases on some occasions, especially during winter.

\section{Spatial distributions of diseases}

The spatial distribution of diseases seems to differ in that Site 4 demonstrated a significant increase in $R R$ for lymphocystis 1 yr earlier than the other sites, while Site 1 had a significant increase in $R R$ for epidermal papilloma 1 yr prior to the other stations. However, when considering the Mantel-Haenszel weighted $R R$ adjusted for sites, the effect of oxygen deficiency is reflected in a significant increase in the $R R$ for both lymphocystis and epidermal papilloma already the year after the first severe oxygen depletion took place. Additionally, no statistically significant difference in the annual variations of the $R R$ among sites was observed.

\section{Sexual difference in susceptibility to diseases}

Lymphocystis appeared to be evenly distributed among males and females. However, the $R R$ of lymphocystis in females remained at the 1984 to 1986 level 1 yr longer than observed for males, after which it increased to the 'male level'. There are no clear indications on the background for this observation. There was no difference among the sex ratios in 1986, 1987 and 1988 that might explain the delayed response observed in the females.
Vitinsh \& Baranova (1976) observed a higher prevalence of lymphocystis in male than in female flounder Calculations based on their presented data demonstrate an $R R$ for females having the disease compared with males ranging from 0.26 to 0.58 . The difference was only statistically significant at 1 out of 7 sites. Similarly, Vethaak (1992) found a significantly higher prevalence of lymphocystis in male than in female flounders along the Dutch coast.

Based on figures on dab presented in Dethlefsen et al. (1987), investigations in the German Bight area in January 1981 demonstrated an $R R$ of 1.22 for females being infected by lymphocystis compared to males. This observation corresponds with our findings of an even $R R$ for both sexes. An even proportion of males and females infected by lymphocystis was also reported in yellowfin sole Limanda aspera Pallas (McCain et al. 1979). The observed difference between dab and flounder indicates that there might be a difference in the infection pattern in different fish species.

In contrast to lymphocystis, epidermal papilloma revealed a significant increase in the $R R$ for females the year after the occurrence of oxygen deficiency, while a significant response in males was observed only in 1989. A possible explanation for this observation is that the females have a significantly higher risk of contracting epidermal papilloma than males, i.e. 2.8 times. Similar observations were made in the German Bight area in January 1981 (Dethlefsen et al. 1987). Calculation of the $R R$ based on their presented data demonstrated a significantly higher risk for females of contracting epidermal papilloma than for males, i.e. 2.3 times. Most female dab had spawned in May in the Kattegat, and this might explain the sexual difference in the susceptibility to epidermal papilloma as female fish in the postspawning period are often in a weak condition. However, if this was the case one would also expect female dab to have a higher risk of getting lymphocystis than males, which is not true. So, it is not clear why females are more susceptible to epidermal papilloma than males.

As for epidermal papilloma, the $R R$ of getting skin ulcers was significantly higher ( 3.7 times) in females than in males. Of the $19 \mathrm{dab}$ with skin ulcers, 13 were between 20 and $25 \mathrm{~cm}$, and within this length group females made up $67 \%$ of the whole population. The mean length of ulcerated female dab $(21.5 \mathrm{~cm})$ was not significantly different from the mean length of ulcerated males $(20.3 \mathrm{~cm})$. Therefore, the higher risk for ulcerations in female fish is probably because females are longer than males. This fits in with our assumption. that most of the skin ulcers observed during this study were primarily due to traumatic skin damage caused by fishing gear, as large fish are more likely to get stuck in the meshes of these gears. 
Field investigations are seldom able to present clearcut proof of the association between specific environmental parameters and the outbreak of fish diseases, as the initial stressors often have a multifactorial background. An attempt to establish a cause-effect relationship is even more difficult when the environmental. impact gradually builds up and has a relatively long duration, which gives the fish the opportunity to adapt to the system. However, the present study clearly indicates that oxygen deficiency, especially sublethal oxygen levels, is a very important stress factor for viral diseases such as lymphocystis and epidermal papilloma. Laboratory experiments need to be established to further clarify the implications of different oxygen levels on the outbreak of fish diseases.

The strong association between oxygen deficiency and lymphocystis and epidermal papilloma demonstrated in the present work is apparently not a phenomenon solely localised to the Kattegat region. There are also indications that oxygen depletion is involved in the dynamics of fish diseases in the North Sea (Mellergaard \& Nielsen 1987).

Acknowledgements. We thank M.s I. Hornum for excellent technical assistance, Dr O.V. Olsen for extracting the oxygen data from the ICES Hydrographic Service Database and the crew of RV 'Dana' for excellent collaboration during the cruises.

\section{LITERATURE CITED}

Anon (1989) Methodology of fish disease surveys. ICES Coop Res Rep 166

Bagge $O(1970)$ The reaction of plaice to transplantation and taggings. A study on mortality, growth and the economic yield of transplantation. Medd Danm Fisk Havunders NS $6: 153-332$

Banning P van (1987) Long-term recording of some fish diseases using general fishery research surveys in the southeast part of the North Sea. Dis aquat Org 3:1-11

Bloch B, Mellergaard S, Nielsen E (1986) Adenovirus-like particles associated with epithelial hyperplasias in dab, Limanda limanda (L.). J Fish Dis 9:281-285

Brett JR, Blackburn JM (1981) Oxygen requirements for growth of young coho (Oncorhynchus kisutch) and sockeye (O. nerka) salmon at $15^{\circ} \mathrm{C}$. Can J Fish Aquat Sci 38: $399-404$

Bucke D, Nicholson MD (1987) Fish disease investigations in the Irish Sea. Comm Meet int Coun Explor Sea CMICES/E:19

Bucke D, Norton MG, Rolfe MS (1983) The field assessment of effects of dumping wastes at sea: II. Epidermal lesions and abnormalities of fish in the outer Thames Estuary. Fish Res Tech Rep 72:1-16

Bucke D, Vethaak AD, Lang T, Mellergaard S (1995) Training guide for the identification of common diseases and parasites of fish in the North Atlantic. ICES Coop Res Rep (in press)

Chiba K (1965) A study on the influence of oxygen concentration on the growth of juvenile common carp. Bull Freshwat Fish Res Lab Tokyo 15:35-47
Christensen NO (1980) Diseases and anomalies in fish and invertebrates in Danish littoral regions which might be connected with pollution. Rapp P-v Réun Cons int Explor Mer 179:103-109

Dean AD, Dean JA, Burton AH, Dicker RC (1990) Epi Info, version 5: a word processing, database and statistics programme for epidemiology on micro-computers. USD, Stone Mountain, GA

Despres-Patanjo L, Ziskowski J, Murchelano RA (1982) Distribution of fish diseases monitored on stock assessment cruises in the western North Atlantic Comm Meet int Coun Explor Sea CM-ICES/E:30

Dethlefsen V (1980) Observations on fish diseases in the German Bight and their possible relations to pollution. Rapp P-v Réun Cons int Explor Mer 179:110-117

Dethlefsen $\vee(1984)$ Diseases in North Sea fishes. Helgoländer Meeresunters 37:353-374

Dethlefsen V (1990) Ten years fish disease studies of the Institut für Küsten- und Binnenfischerei. Arch FischWiss 40 $119-132$

Dethlefsen V, Watermann B (1982) Diseases of major fish species in western Baltic Sea. Comm Meet int Coun Explor Sea CM-ICES/E: 19

Dethlefsen V, Watermann B, Hoppenheit M (1987) Diseases of North Sea dab (Limanda limanda L.) in relation to biological and chemical parameters. Arch FischWiss 37; $107-237$

Fry FEJ (1969) Some possible physiological stresses induced by eutrophication In: Anon (ed) Eutrophication: causes, consequences, correctives. National Academy of Science, Washington, DC, p 531-536

Haley R, Davis SP, Hyde JM (1967) Environmental stress and Aeromonas liquefaciens in American and threadfin shad mortalities. Prog Fish-Cult 29:193

Hansen IS, Aertebjerg G, Richardson K (1995) A scenario analysis of effects of reduced nitrogen input on oxygen conditions in the Kattegat and the Belt Sea. Ophelia (in press)

Johnstone J (1905) Internal parasites and diseased conditions of fishes. Rep Lancs Sea-Fish Lab 13:98-120

Johnstone J (1925) Malignant tumours in fishes. Rep Lancs Sea-Fish Lab 33:105-136

Kronvang B, Aertebjerg G, Grant R, Kristensen P, Hovmand M, Kirkegaard J (1993) National monitoring of nutrients and their ecological effects: state of the Danish aquatic environment. Ambio 22:176-187

Martin SW, Meek AH, Willeberg P (1987) Veterinary epidemiology. lowa State University Press, Ames

McArdle J, Parker M, Martyn C, Rafferty D (1982) A survey of diseases of marine flatfish from the east coast of Ireland in 1981. Comm Meet int Coun Explor Sea CM-ICES/E:47

McCain BB, Gronlund WD, Myers MS (1979) Tumours and microbial diseases of marine fishes in Alaskan waters. J Fish Dis 2:111-130

McIntyre AD, Pearce JB (eds) (1980) Biological effec-s of marine pollution and the problems of monitoring. Proceedings from ICES Workshop, Beaufort, North Carolina. Rapp P-v Réun Cons int Explor Mer 179:1-346

Mellergaard S, Nielsen E (1984) Preliminary investigations on the eastern North Sea and the Skagerrak dab (Limanda limanda) populations and their diseases. Comm Meet int Coun Explor Sea CM-ICES/E:28

Mellergaard S, Nielsen E (1985) Fish diseases in the eastern North Sea dab (Limanda limanda) populations with special reference to the epidemiology of epidermal hyperplasias/papillomas. Comm Meet int Coun Explor Sea CMICES/E:14 
Mellergaard S, Nielsen E (1987) Influence of oxygen deficiency on the dab populations in the eastern North Sea and the southern Kattegat. Comm Meet int Coun Explor Sea CM-ICES/E: 6

Mellergaard S, Nielsen E (1990) Fish disease investugations in Danish coastal waters with special reference to the impact of oxygen deficiency. Comm Meet int Coun Explor Sea CM-ICES/E:6

Möller H (1981) Fish diseases in German and Danish coastal waters in summer 1980. Meeresforsch 29:1-16

Möller H (1984) Dynamics of fish diseases in the lower Elbe River. Helgoländer Meeresunters 37:389-413

Möller H (1985) A critical review on the role of pollution as a cause of fish diseases. In: Ellis AE (ed) Fish and shellfish pathology. Academic Press, London, p 169-182

Möller $\mathrm{H}$, Anders $\mathrm{K}$ (1983) Diseases and parasites of marine fishes. Verlag Möller, Kiel

Muus BJ (1967) The fauna of Danish estuaries and lagoons. Dictrihution and ecology of dominating species in the shallow reaches of the mesohaline zone. Medd Danm Fisk Havunders NS 5:1-316

Scholz U, Waller U (1992) The oxygen requirements of three fish species from the German Bight: cod Gadus morhua, plaice Pleuronectes platessa, and dab Limanda limanda. J appl Ichthyol 8:72-76

Snieszko SF (1974) The effect of environmental stress on outbreaks of infectious diseases of fish. J Fish Biol 6: $197-208$

Steffensen JF, Lomholt JP, Johansen K (1981) The relative importance of skin oxygen uptake in the naturally buried plaice (Pleuronectes platessa) exposed to graded hypoxia. Respir Physiol 44:269-275

Responsible Subject Editor: C. B. Schreck, Corvallis, Oregon, USA
Stewart NE, Shumway DL, Doudoroff P (1967) Influence of oxygen concentration on the growth of juvenile largemouth bass. J Fish Res Bd Can 24:475-494

Vethaak AD (1991) Fish disease monitoring in the Dutch part of the North Sea in relation to the dumping of waste from titanium dioxide production. Chem Ecol 5:149-170

Vethaak AD (1992) Diseases of flounder (Platichthys flesus L.) in the Dutch Wadden Sea and their relation to stress factors. Neth J Sea Res 29:257-272

Vethaak AD (1993) Prevalence of fish diseases with reference to pollution of Dutch coastal waters. Rivo-Report CA 85 $01 / \mathrm{E}: 1-70$

Vethaak AD, Bucke D, Lang T, Wester PW, Jol J, Carr M (1992) Fish disease monitoring along a pollution transect: a case study using dab Limanda limanda in the German Bight. Mar Ecol Prog Ser 91:173-192

Vitinsh M, Baranova T (1976) Lymphocystis disease in Baltic flounder (Platichthys flesus L.). Comm Meet int Coun Explor Sea CM-ICES/P:6

Weber RE (1993) Effekter af iltsvind og tungmetaller på marine bunddyr. Havforskning fra Miljøstyrrelsen 12

Wedemeyer G (1970) The role of stress in the disease resistance of fishes. In: Snieszko SF (ed) A symposium on diseases of fishes and shellfishes. American Fisheries Society, Washington, DC, p 30-35

Wedemeyer G (1981) The physiological responce of fishes to the stress of intensive aquaculture in recirculation systems. Proc World Symp on Aquaculture in Heated Effluents and Recirculation Systems 2:3-18

Weissenberg $R$ (1951) Positive result of a filtration experiment supporting the view that the agent of the lymphocystis disease of fish is a true virus. Anat Record 111:582

Manuscrupt first received: September 6, 1994

Revised version accepted: January 6, 1995 